\title{
BIM and Lean Construction: The Evolution Obstacle in the Brazilian Civil Construction Industry
}

\author{
Thomas Wünsch Alvarenga \\ Civil Engineering Department \\ Fluminense Federal University \\ Niterói, Brazil \\ twalvarenga@gmail.com
}

\author{
Edson Neves da Silva \\ Civil Engineering Department \\ Fluminense Federal University \\ Niterói, Brazil \\ engproducao.edson@gmail.com
}

\author{
Luiz Carlos Brasil de Brito Mello \\ Civil Engineering Department \\ Fluminense Federal University \\ Niterói, Brazil \\ luiz.brasil@gmail.com
}

\begin{abstract}
This article presents the teaching approach of different universities in the state of Rio de Janeiro regarding the dissemination of two civil construction learning paradigms: BIM and Lean Construction. The article's main purpose is to investigate the learning systems of the two techniques for the benefit of the construction industry, as well as to evaluate their level of recognition. The principal results show that civil engineers graduates acquire little or no knowledge of both techniques, which may become a barrier to their professional evolution and especially to their involvement with public works projects.
\end{abstract}

\section{Keywords-BIM; lean construction; universities}

\section{INTRODUCTION}

The Brazilian construction industry is known as the least technological, compared to industries in other segments, and deficient in the management of its ventures. The perception of a high level of production within the sector in recent years is not characterized by a high level of productivity. Although production and productivity are closely linked, a company, an economic sector, or a country, are said to be competitive if they produce efficiently, that is, they make the best use of available resources [1]. Increased production cost can be the result of increased costs of hiring of employees, materials, and equipment. In order to organize this discussion about productivity, authors in [2] reported seven points of leverage relevant to such objectives: planning project execution, management methods adoption, equipment, materials, constructive methods, project improvements and workforce qualification. The study revealed the urgent need for increased productivity in construction in Brazil. Thus, companies need to adopt a comprehensive productivity-enhancing program with multiple coordinated initiatives. All relations addressed toward improving productivity point to the improvement of efficiency in the construction sector by means of using new technologies, new construction processes, specialized labor, materials, manpower and equipment coordination. In order to bring construction to a satisfactory level of efficiency and productivity, new paradigms in civil construction are presented, such as Building Information Modeling (BIM) and Lean Construction philosophy. These two approaches are shown as the grand proposal to improve efficiency in the construction industry. However, for this to happen, it is necessary to evaluate how much is known about these techniques, the recognition of their benefits, and what type of dissemination strategy is being used within a context such as universities, whose main objective is to train professionals working in the construction sector, such as civil engineers.

The objective of this research is to investigate the extent to which universities in the state of Rio de Janeiro support the dissemination of BIM and Lean Construction.

\section{THEORETICAL BACKGROUND}

\section{A. BIM (Building Information Modeling)}

BIM technology presents itself as a solution with great potential for the construction industry, since it enables the sharing of a digital model that is common to all those involved in its process, in a consistent way, and that can handle the whole life cycle of the construction project [3]. Most recent works present many definitions to describe BIM. The most recognized one, is BIM as a product or intelligent digital representation of a set of structured data that define a building [4]. Another one is BIM as a collaborative process that represents a business structure for work and communication based on the use of open standards of information sharing, which improves quality and efficiency in projects [3]. One more definition presents BIM as a facility management tool throughout the enterprise lifecycle, providing a reliable, verifiable, transparent and sustainable information base which teams use in the operation of the facility throughout its entire life cycle [5]. BIM brings numerous benefits to the construction industry, such as significant productivity improvements, projects that are more efficient, faster production and details, improved support for automating and reducing errors due to internal coordination [6]. When adopted with full awareness of its potentialities, BIM enables the integration of the design and construction process, resulting in better quality works, lower costs and shorter project execution time [7].

\section{B. Lean Construction}

With the publication of [8] began the transfer and adaptations of concepts and principles from the Toyota 
Production System into the construction industry [9-11]. The study challenges construction professionals to break their management paradigms and adapt techniques and tools successfully developed in the TPS [12]. Production is defined as a flow of materials and/or information from raw material to finished product [8]. Lean Construction emphasizes the importance of production process flow, based on three concepts.

- The transformation of input into output, in which production management equalizes the total decomposition of transformation into elementary transformations by task, seeking minimum cost and maximum efficiency [14].

- The activities of waiting, inspection and movement to the next stage, in which production management seeks to reduce this variability in the production flow [14].

- The fulfillment of customer needs, in which production management seeks to translate customer needs into product or service [14].

Lean Construction is defined by a set of interconnected principles that should be applied in an integrated way in the management of processes to obtain the expected results [8]. These principles are basically: reduce the share of activities that do not add value, increase product value by considering costumer needs, reduce process variability, reduce cycle time, simplify by reducing the number of steps or parts, increase output flexibility, increase process transparency, focus control on overall process, introduce continuous process improvement, maintain balance between improvements in flows and conversions, and finally benchmarking [8]. The Lean concept is one of the most successful philosophies for production systems such as construction, as it depicts, through its tools, ways of controlling waste and anticipating uncertainties [15].

\section{Universities and Engineering Education.}

Universities' main function is to train professionals. National curricular guidelines for engineering programs include a generalist, humanistic, critical and reflexive education, capable of absorbing and developing new technologies, stimulating their critical and creative role in identifying and solving problems $[16,17]$. With a complete higher education, the engineer is a professional who develops his/her activity in a technology area, whose responsibility is to produce technology and to operate the industrial processes generating goods for society, from the available scientific production systems [18]. However, constant updates and radical changes may be required in order for courses to follow the vast changes in the industry and economy [19]. Four major challenges to engineering programs are presented by several authors:

- the challenge to change teachers' and students' perception that the degree program is merely business training, denying the validity of basic subjects and humanistic conception for the academic training of the engineer [18, 19]

- the challenge of adding flexibility to engineering programs, since their technological aspect has been advancing with increasing rate [19]
- the challenge of the acquisition of an interdisciplinary technological curriculum, aimed at the integration of theoretical and empirical knowledge such as project courses that make use of established methods and technology whilst introducing groundbreaking tools (BIM software, for instance) that will improve production, quality and cost. That is necessary in order to avoid performing activities without a systemic direction and teaching subjects without connection, with repeated and autonomous content.

- the challenge of the determination of a pedagogical line for this curriculum, defined and assimilated by the entire community involved in a participatory, democratic and conscious process, with autonomy to define and approve parameters and regulations inherent to the curricular process.

\section{RESEARCH METODOLOGY}

This research is presented as exploratory, where the objective is to carry out a survey of relevant information on the topics addressed. The case study focused on assessing, through a questionnaire sent to public universities (state and federal), questions regarding the degree of knowledge, recognition and actions for the dissemination of concepts, techniques and tools of BIM and Lean Construction. Questionnaires were prepared, tested and sent individually to 6 universities in the state of Rio de Janeiro that offer bachelor degrees in civil engineering. The sampling plan was classified as non-probabilistic and the questionnaire was sent to the entire sample. The sample size was stablished by considering the universe (Metropolitan area of Rio de Janeiro and adjacencies) thereby granting a population of approximately 560 professors of Civil Engineering and Architecture. The obtained sample size was a total of 89 respondents. In the exploratory analysis of qualitative data, the usual measure is mode, and thus the results are represented by bar graphs or circular diagrams [11].

\section{CASE STUDY}

\section{A. General Aspects}

The research focuses on public universities (state and federal) located in the metropolitan area of Rio de Janeiro and adjacencies that had Civil Engineer and Architecture courses. There are 6 institutions inside the considered area and they were all included in the research. The capital of the state of Rio de Janeiro has significant importance within the national and international level. It is the second largest metropolis in Brazil, and one of the main economic, cultural and financial centers, and representing the country's second largest gross domestic product contributor (GDP). The study was conducted between April and November 2016, and return rates were $83.3 \%$ for the BIM survey and $66.0 \%$ for the Lean Construction survey in a sample field of 6 educational institutions. For reasons of confidentiality, interviewees and institution names will not be disclosed.

Items addressed in the first stage of surveying interviewee and institutional profiles are summarized below: 
- Respondent posts: $100 \%$ undergraduate course professors in Civil Engineering.

- Time in position: $100 \%$ above 5 years.

- Educational Degree: $100 \%$ PhDs.

\section{B. Results Obtained Through the Lean Construction Research.}

Results are shown in Figures 1-5 and further discussion follows. Figure 1 shows how the statement by the universities was divided on the issue of whether content about the Lean Construction philosophy is actually taught. The chart shows unanimity in the outcome of the issue, as all 4 universities agree that Lean Construction is taught at the universities of Rio de Janeiro state. This question did not seek however to measure how much of this content is taught, which is seen in Figure 2. The result demonstrates that such content involving concepts, techniques and tools is taught at low to very low, within the civil engineering program. Figure 3 demonstrates the assessment as to the proof of the effectiveness level of Lean techniques and tools for the benefit of civil construction. Respondent insights indicate them to range from mid to high. The result shows an understanding by portions of the respondents, ranging from high to very high, of the philosophy's relevance to current and future Civil Engineers in the construction industry context.

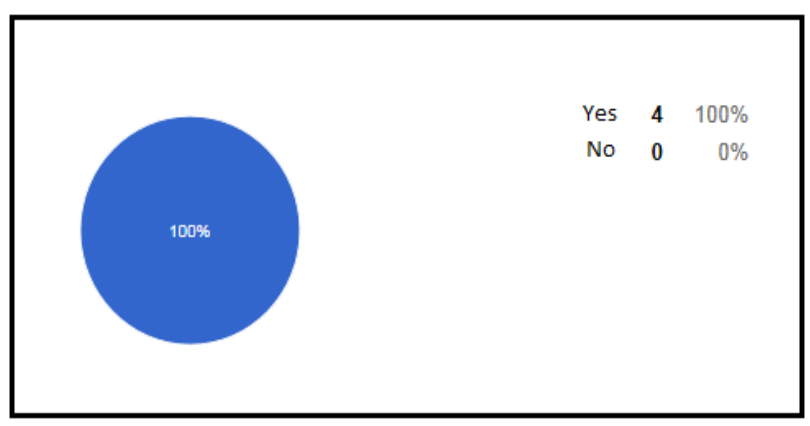

Fig. 1. Result obtained on declaration of teaching Lean Construction at the Universities

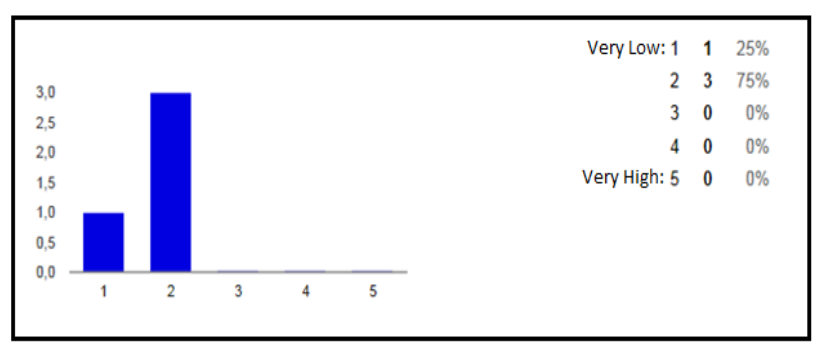

Fig. 2. Result obtained on the level of teaching of Lean Construction at the Universities

Figure 5 demonstrates the results about what types of disciplines the Lean Construction philosophy content would fit better, in the opinion of academics. The result shows that there is a division among respondents about the kind of program where Lean content could be presented. Among their responses, $50 \%$ indicated it as an optional course subject in the civil engineering program, and the other $50 \%$ as an optional course subject in all engineering programs. There was no indication for Lean Construction concepts in compulsory courses. This question was aimed at analyzing, in another way, the level of importance of the Lean Construction Philosophy for the academics. Figure 4 demonstrates the importance of Lean Construction for the current and future Civil Engineer as perceived by the university. An evaluation of the importance of disseminating the concepts of the philosophy to professionals was sought.

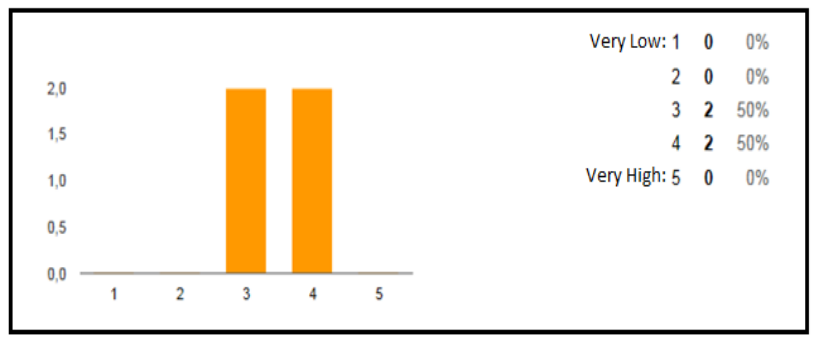

Fig. 3. Result obtained on the proof of efficacy level of Lean Construction philosophy at the Universities

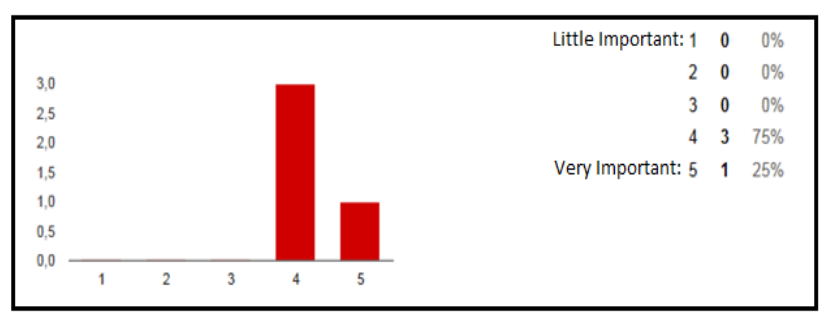

Fig. 4. Result obtained on the importance of Lean Construction for the Engineering profession

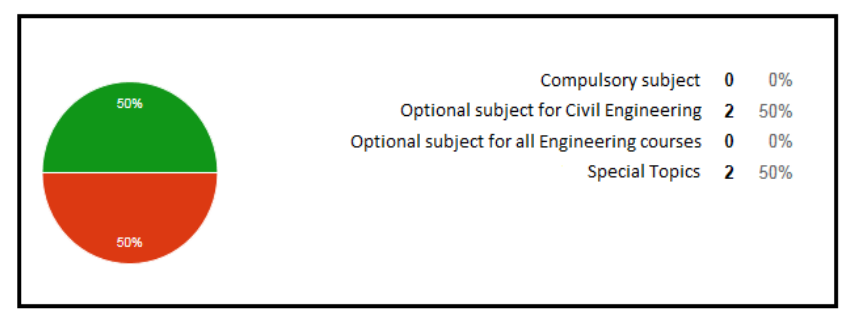

Fig. 5. Result obtained on identifying the type of material for Lean Construction at the Universities

\section{Results Obtained Through the BIM (Building Information Modeling)Rresearch.}

Figure 6 shows how the statement of the universities was divided on the issue of whether content about the BIM philosophy is taught at the universities. The graph shows unanimity in the question's result. All 5 respondent universities stated that BIM is taught at the universities in Rio de Janeiro. This question did not seek to measure how much of this content is taught, which can be seen in Figure 7 which shows that BIMrelated content involving concepts, principles, techniques and 
tools are taught at very low levels. Figure 8 demonstrates the perception by the university of the importance of BIM. The aim was to evaluate the perceived importance of disseminating concepts of the philosophy among professionals. The graph shows that most participants declare that it is very important to disseminate BIM concepts, techniques and tools to civil engineering professionals. Figure 9 illustrates the percentage distribution of benefits associated with the implementation of BIM from the respondent's perspective. Integrated collaboration of all involved parties in the project is perceived as the main benefit that BIM can promote for civil construction projects, with a $69 \%$ indication, followed by the possibility of use throughout the life cycle of a project, with a $14 \%$ indication. In a manner similar to that for the benefits of BIM, respondents were asked to point out the following barriers to the dissemination of BIM. Figure 10 illustrates the percentage distribution associated with the main constraints associated with BIM implementation from the respondent's perspective. According to the respondents, the lack of technical knowledge on the part of the teachers represents the greatest obstacle in the implementation of BIM at the universities, followed by the impossibility of teaching BIM content in the current curriculum.

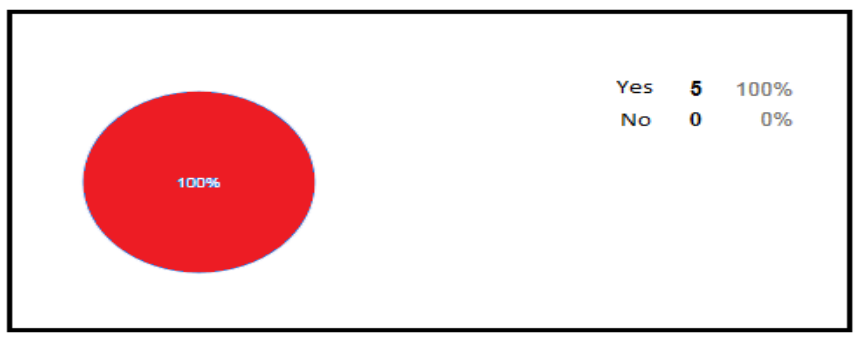

Fig. 6. Result obtained from the declaration on teaching BIM at the Universities

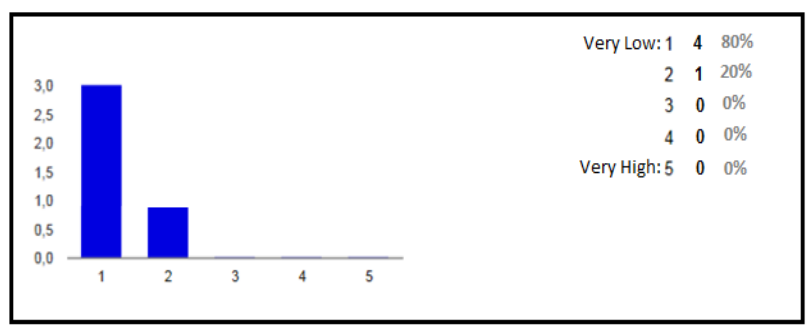

Fig. 7. Results obtained on BIM teaching level at the Universities

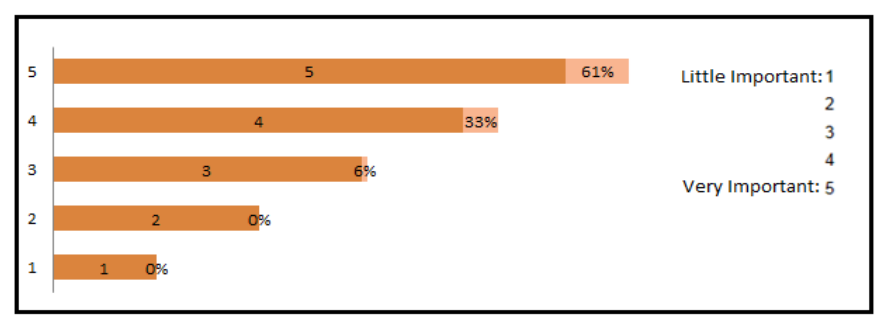

Fig. 8. Result obtained on the importance of BIM for the Civil Engineering professional.

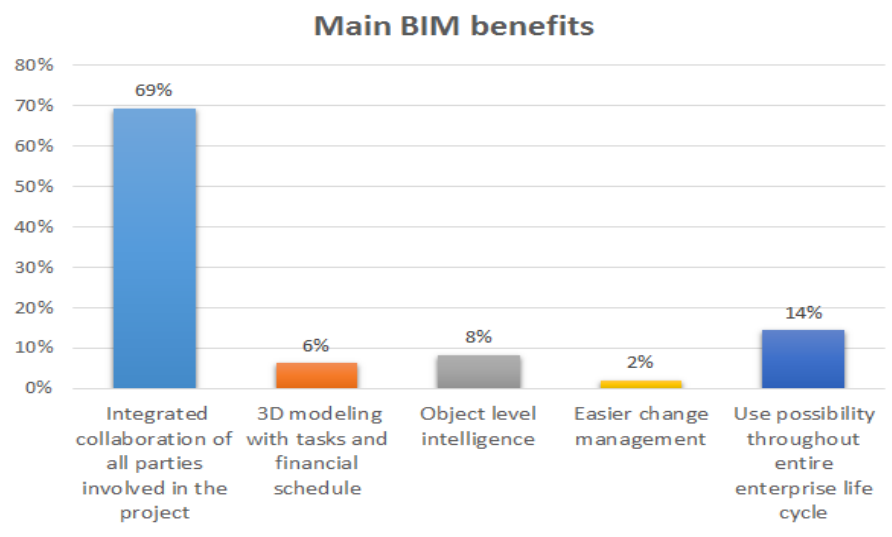

Fig. 9. Percentage representation associated with the main benefits coming from BIM implementation as perceived by respondents.

\section{Main obstacles to BIM implementation}

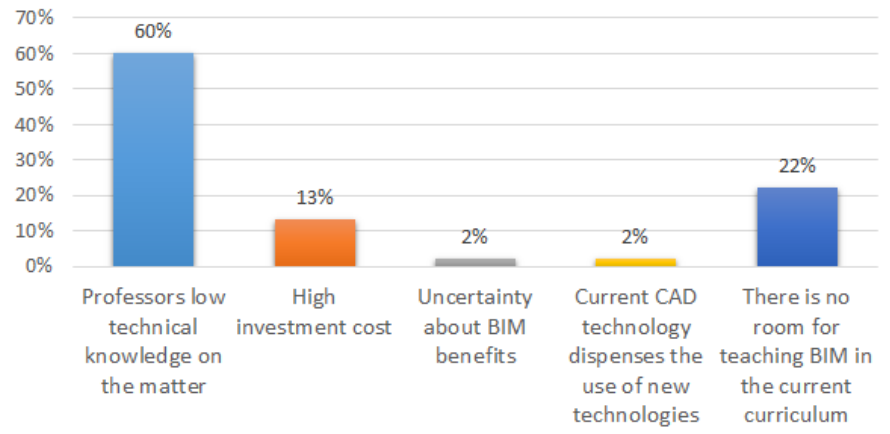

Fig. 10. Percentage representation associated with the main obstacles for BIM implementation, as perceived by respondents.

\section{CONCLUSIONS}

Building Information Modeling and Lean Construction are two rather promising approaches aiming to improve efficiency in the construction industry. Thus, incorporating their teaching in civil engineering courses is rather important for both industry and academia. The present paper focuses at universities located Rio de Janeiro and their aspects on these two techniques. Results show that although both aspects are known and their value is recognized, the level of the content taught is evaluated as low to very low. This is attributed to the relatively low technical knowledge of the teaching staff and to the high investment costs required.

\section{REFERENCES}

[1] Camara Brasileira Da Industria Da Construcao, Produtividade da construcao civil, Brasília, FGV Projetos, 2012

[2] Ernst \& Young, Estudo sobre a produtividade na Construcao Civil Objetivos e Tendencias no Brasil, Sao Paulo, 2014

[3] C. Eastman, P. Teicholz, R. Sacks, K. Liston, BIM Handbook - A Guide to Building Information Modeling for Owners, Managers, Designers, Engineers and Contractors, 2nd Edition, Bookman, 2014

[4] General Services Administration (GSA) - GSA BIM Guide Series 01 BIM Guide Overview, 2007. 
[5] National Institute of Building Sciences, United States national building information modeling standard, Version 1 - Part 1: Overview, principles, and methodologies, 2007.

[6] C. Eastman, G. Lee, R. Sacks, "Development of a knowledge-rich CAD system for the North American Precast Concrete industry", Proceedings of the 2003 Annual Conference of the Association for Computer Aided Design in Architecture, Indianapolis, 2003

[7] R. Sacks, B. Dave, L. Koskela, R. Owen, "Analysis framework for the interaction between lean construction and building information modeling", 17th International Group for Lean Construction Conference, 2009

[8] L. Koskela, Application of the new production philosophy to construction. Center for Intergrated Facility Engineering Technical Report \#72, Stanford University, Palo Alto, California, 1992

[9] V. D. S. D. Azevedo, Planejamento de Atividades da Construcao Predial Visando a Reducao de Perdas de Processo na Otica da Construcao Enxuta, Programa de Pos-graduacao em Engenharia Civil - Area de Concentracao, Estruturas, Dissertation, Universidade do Estado do Rio de Janeiro, 2010

[10] I. R. Bulhoes, Diretrizes para implementacao de fluxo continuo na construcao civil: Uma abordagem baseada na mentalidade enxuta, $\mathrm{PhD}$ Thesis, Universidade Estadual de Campinas, Campinas, 2009

[11] P. A. C. Miguel, L. L. Ho, Metodologia de Pesquisa em Engenharia de Producao e Gestao de operacoes, 2nd edition, Rio de Janeiro, 2012

[12] C. T. Formoso, "Lean Construction: principios basicos e exemplos, In: Construcao Mercado: custos, suprimentos, planejamento e controle de obras", Porto Alegre, Vol. 15, p. 5058, 2002

[13] L. S. Carvalho, Adocao dos princípios Lean pelo setor da Construcao Civil, MSc Thesis, Federal University of Rio de Janeiro, 2013

[14] L. Koskela, An exploration towards a production theory and its application to Construction, $\mathrm{PhD}$ Thesis, Helsinki University of Technology, Finland, 2000

[15] J. M. F. Pinto, "Lean Construnction Proposta de Metodologia de Avaliacao de Projetos de Construcao", MSc Thesis, University of Porto, 2012

[16] E. Padilha, "O papel das entidades de classe na nova visao do sistema CONFEA/CREA", 8th National Congress of Professionals, Brasilia, 2013

[17] Brasilian Ministry of the Environment, Sustainable construction, 2012, available at: http://www.ambiente.gov.br/cidades-sustentaveis/urbani smo-sustentavel/itemlist/category/66-urbanismo-sustentavel

[18] J. B. Laudares, A formacao do engenheiro em duas instituicoes mineiras: o Centro de Educacao Tecnologica de Minas Gerais e o Instituto Politecnico da Pontifícia Universidade Catolica de Minas Gerais, Centro Federal de Educao Tecnologica de Minas Gerais, 1992

[19] J. P. Batista, Um estudo comparativo dos cursos de engenharia civil e engenharia de producao civil em oferta em Belo, MSc Thesis, 2003 